\title{
Preparation and application of metal ion-doped CoMgAl-hydrotalcite visible-light-driven photocatalyst
}

\author{
Ali Auwalu ${ }^{1} \cdot$ Tong Linlin $^{1} \cdot$ Shamsu Ahmad ${ }^{2} \cdot$ Yang Hongying $^{1}{ }^{1} \cdot$ Jin Zhenan $^{1} \cdot$ Yan Song $^{1}$
}

Received: 25 September 2018 / Accepted: 14 March 2019 / Published online: 11 April 2019

(c) The Author(s) 2019

\begin{abstract}
Preparation and application of CoMgAl-hydrotalcites have been studied. In this paper CoMgAl-LDHs photocatalysts were prepared by co-precipitation. Various techniques such as UV-visible spectrometry (UV-vis), BET, differential thermal gravimetric analysis, scanning electron microscopy analysis and X-ray diffraction were used to investigate the catalytic activity, structure, and composition of the prepared samples. The photocatalysts were developed as layered double hydroxides (LDHs) due to their layered structure with $\mathrm{OH}^{-}$. In the paper, specific surface area, thermal stability, absorption of visible light, and layered structure (crystal phase) were characterized by nitrogen adsorption-desorption method, differential thermal gravimetric analysis, UV-vis methods and X-rays diffraction. The results indicated that CoMgAl-LDHs caused photocatalytic degradation of methyl orange, rhodamine talcum, and methylene blue. Initially $1 \mathrm{~g} / \mathrm{L}$ of the photocatalyst was used to degrade $40 \mathrm{mg} / \mathrm{L}$ of methyl orange, it was observed that $85.7 \%$ of the methyl orange was degraded at an illumination time of $300 \mathrm{~min}$. However, the degradation of rhodamine and methylene blue was not good and did not give better results as that of methyl orange.
\end{abstract}

Keywords Hydrotalcite $\cdot$ Photocatalyst $\cdot$ Absorption $\cdot$ Degradation

\section{Introduction}

Wastewater from dye industry has been considered as an important source of water pollution in the world due to its highly colored nature and refraction to degradation. Research on photocatalyst carried out in 1970s was commenced by irradiation of $\mathrm{TiO}_{2}$ photo-electrodes under irradiation of UV light and resulted in the decomposition of water to form oxygen and hydrogen [1-3]. Choi et al. investigated the photo reactivity of 21 metal ions that were doped into $\mathrm{TiO}_{2}$. It was found that when the metal ions were doped, they expanded $\mathrm{TiO}_{2}$ photo response into visible spectrum. However, when metal ions are added into $\mathrm{TiO}_{2}$, impurity and lattice energy levels were formed in the gap of $\mathrm{TiO}_{2}$. As represented in Eqs. 1 and 2 below.

$\mathrm{M}^{n+}+h v \rightarrow \mathrm{M}^{(n+1)+}+\mathrm{e}_{\mathrm{ch}}^{-}$

Yang Hongying

yanghy@smm.neu.edu.cn

1 School of Metallurgy, Northeastern University, Shenyang 110819, China

2 Federal University Dutse, Dutse PMB 7156, Jigawa State, Nigeria
$\mathbf{M}^{n+}+h v \rightarrow \mathbf{M}^{(n-1)+}+h v_{v b}^{-}$

where $\mathrm{M}^{n+} \& \mathrm{M}$ are metal ion dopant and metal, respectively.

The electron hole transfer between $\mathrm{TiO}_{2}$ and metal ion can alter the holes' recombination as shown in Eqs. 3 and 4.

Hole trap: $\mathrm{M}^{n+}+h_{v b}^{+} \rightarrow \mathrm{M}^{(n-1)-}$

Electron trap: $\mathrm{M}^{n+}+\mathrm{e}_{\mathrm{cb}}^{-} \rightarrow \mathrm{M}^{(n-1)+}$

Furthermore, a main drawback of any powder form is that either the process has to be conducted in a suspension or the photocatalyst has to be immobilized on a carrier by compacting [4]. Mohsen et al. investigated in situ manganese doping of $\mathrm{TiO}_{2}$, single-step electrochemical anodizing titanium, such as Sulfur-dope $\mathrm{TiO}_{2}$, copper-decorated tungsten oxide- $\mathrm{TiO}_{2}$ nanotubes, iron-decorated tungsten-titania, tungsten-copper co-sensitized $\mathrm{TiO}_{2}$ nanotube composite photo anodes [5-8]. Fe/WTNs photocatalytic activities were evaluated by degradation of aqueous Rhodamine B under xenon lamp radiation. It was discovered that the photocatalytic degradation reaction depends on many factors, such as the absorption of the dye on the catalyst surface, band 
gap energy, surface area, pore diameter, crystallinity, and electron-hole recombination rate [9-12].

$\left[\mathrm{M}_{(1-x)}^{2+} \mathrm{M}_{x}^{3+}(\mathrm{OH})_{2}\right]\left(A_{x / n}^{n-}\right) \cdot m \mathrm{H}_{2} \mathrm{O}$

where $\mathrm{M}^{2+}$ represents the divalent cations such as $\mathrm{Mg}^{2+}$, $\mathrm{Fe}^{2+}, \mathrm{Ni}^{2+}, \mathrm{Cu}^{2+}, \mathrm{Co}^{2+}, \mathrm{Mn}^{2+}, \mathrm{Zn}^{2+}$ or $\mathrm{Cd}^{2+}, \mathrm{M}^{3+}$ denotes the trivalent cations like $\mathrm{Al}^{3+}, \mathrm{Cr}^{3+}, \mathrm{Ga}^{3+}$ or $\mathrm{Fe}^{3+}, A^{n-}$, is the compensating anions $\left(\mathrm{CO}_{3}{ }^{2-}, \mathrm{SO}_{4}{ }^{2-}, \mathrm{Cl}^{-}, \mathrm{NO}_{3}{ }^{-}\right.$, organic anions), $A^{n-}$ is an interlayer $n^{-}$valent anion and $x$ varies between approximately 0.25 and 0.33 and $m$ is the content of co intercalated-water $[13,14]$. In the process of photocatalysis and fabrication, LDH-based photocatalysts are generally subjected to a variety of synthesis methods. However, some major challenges include simplifying the synthesis process with high crystallinity, high dispersion and adequate exposure of the active sites, precise control of particle size and morphology and long-term catalytic stability are encountered [15]. Various catalysts such as polyaniline $\mathrm{Zr}(\mathrm{IV})$ selenotungstophosphate nanocomposite (PANI/ZSWP nanocomposite) were prepared as a photocatalytic agent for dye degradation and as antimicrobial agent, such as the removal of harmful hazardous MB and MG dyes from water system and treatment of diseases causing pathogens [16]. A family of visible light-responsive $\mathrm{Ni}-\mathrm{Zn} / \mathrm{Cr}-\mathrm{CO}_{3}{ }^{2-}$ ternary $\mathrm{LDHs}$ was synthesized by a co-precipitation method with varying the Ni/Zn atomic ratio. The study suggested that properly incorporating transition metals into the brucite layer of LDHs with suitable band edges might be a promising alternative for developing visible light-responsive ternary systems for hydrogen evolution [17]. Kulamani Parida et al. evaluated the photocatalytic activity via the photo-degradation of various colored and colorless pollutants under solar light, it was found that $\mathrm{ZB}_{\mathrm{Hy}} 4 \mathrm{LDH}$ exhibited much higher photocatalytic activity than ZB4 LDH. The enhanced photocatalytic activity of $\mathrm{ZB}_{\mathrm{Hy}} 4 \mathrm{LDH}$ is attributed to high crystallinity and phase purity, low recombination of charge carriers, long lifetime of photo-generated charges etc. [18]. The thermal stability of $\mathrm{Cu}-\mathrm{Cr} \mathrm{LDH}$ increased by increasing $\mathrm{Co}$ amount in the brucite layer and photocatalyst exhibits high photocatalytic activity in the visible region due to the cooperative effect of binary cations and more electron-transfer capability of cobalt along with uniform pore size distribution [19]. OG/ $/ \mathrm{La}_{2} \mathrm{O}_{3} / \mathrm{ZrO}_{2}$ nanocomposite has been fabricated by co-precipitation method. OG sheets provided high surface area for the adsorption of dyes to take place and the deposition of other two metal oxides onto the OG helped in suppressing the electron-hole pair recombination ability thus, leading to high photocatalytic activity of $\mathrm{OG} / \mathrm{La}_{2} \mathrm{O}_{3} / \mathrm{ZrO}_{2}$ towards the degradation of fast green dye [20]. The photocatalytic activity of ChPA/ZS nanocomposite was measured by the photo-degradation of Congo red and methyl orange dyes under solar light radiations and the results indicated that chitosan-g-poly(acrylamide)/ZnS nanocomposite had an ability for dye removal under simultaneous adsorption and photo-degradation [21]. A novel PAM/NZP nanocomposite has an efficient adsorbing power and visible light photoactivity. The utilization of photon energy from a wider spectrum of solar light, lower electron-hole recombination, and simultaneous adsorption leads to degradation of rhodamine $\mathrm{B}$ and malachite green [22]. $\mathrm{CeMoPO}_{4}$ and $\mathrm{GA} / \mathrm{CeMoPO}_{4}$ nanocomposites were investigated for their photocatalytic activity using methyl violet as test contaminate. The degradation results revealed that the $\mathrm{GA} / \mathrm{CeMoPO}$ has better photocatalytic activity [23]. Many researchers have studied different synthesis methods through a lot of work on the preparation of LDHs, such as, ultra-sonication method [24], facile weight impregnation method [25] but mature synthesis methods include co-precipitation [26, 27], hydrothermal synthesis [28-30], microwave radiation, ion exchange chromatography, sol-gel method [31,32], etc. Co-precipitation method is the most basic and commonly used synthetic method of hydrotalcite. Co-precipitation method is done in two different forms: co-precipitation at variable $\mathrm{pH}$ and at constant $\mathrm{pH}$. The co-precipitation at constant $\mathrm{pH}$ results in particles with greater uniformity [14]. However, the structural environments and dynamical behavior of the interlayer and surface species of hydrotalcites are difficult to study and poorly understood. A number of papers dealing with systems containing one divalent and one trivalent cation exist. But only a few systems containing two divalent and one trivalent ( $\mathrm{Co}-\mathrm{Mg}-\mathrm{Al})$ cation have been reported [33-35]. Shekoohi et al. [36] successfully prepared $\mathrm{Co}-\mathrm{Mg}-\mathrm{Al}$ Nano hydrotalcites, the crystallinity and crystallite size of the hydrotalcite were observed to vary with $\mathrm{M}^{2+} / \mathrm{M}^{3+}$ molar ratio. The increase of $\mathrm{M}^{2+} / \mathrm{M}^{3+}$ ratio causes changes in the layer spacing and particles sizes become larger. $\mathrm{Co}-\mathrm{Mg}-\mathrm{Al}$ nano hydrotalcites have larger particle size than $\mathrm{Mg}-\mathrm{Al}$ nanohydrotalcites.

In this paper, ternary Hydrotalcite $(\mathrm{Co}-\mathrm{Mg}-\mathrm{Al})$ with different Co molar ratio (4:2:1, 2:2:1,1:2:1, and 0.5:2:1) was prepared and the influence of Co molar ratio on the structure and performance of the prepared samples on degradation of methyl orange, rhodamine talcum and methylene blue was studied (Fig. 1).

Methyl orange (di-methyl-amino azo-benzene sulfonate) belongs to the azo dyes with maximum absorption wavelength at $464 \mathrm{~nm}$. Due to its high-Chroma, well-defined optical absorption characteristic, it can easily be absorbed onto catalyst from its aqueous solution, strong toxicity, and potential carcinogenic aromatic amine, which is listed as one of the most in urgent need of treatment in wastewater. Thus, in this paper methyl orange was chosen as the processing object, the photocatalytic activity of the sample catalysts on methyl orange 


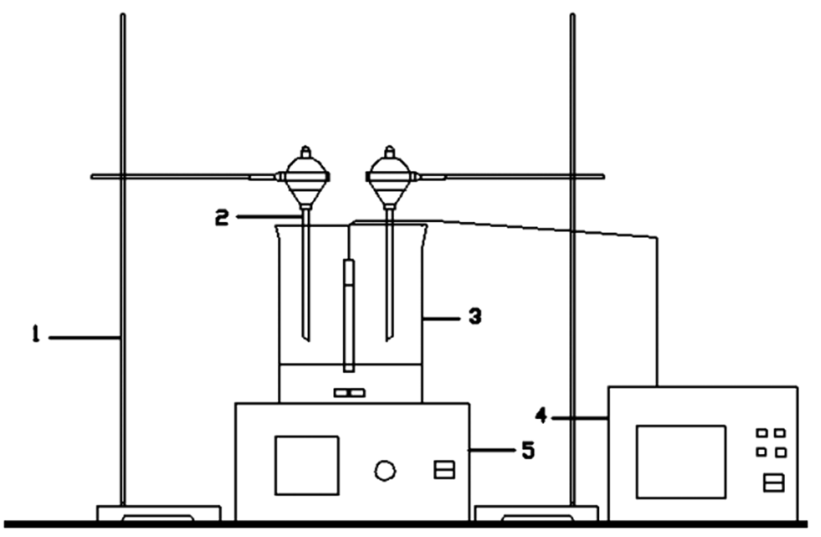

Fig. 1 Schematic diagram of the samples preparation set-up. 1. Apparatus stand. 2. Separating funnel. 3. Beaker. 4. Automatic potentiometer titrator. 5. Temperature magnetic stirrer

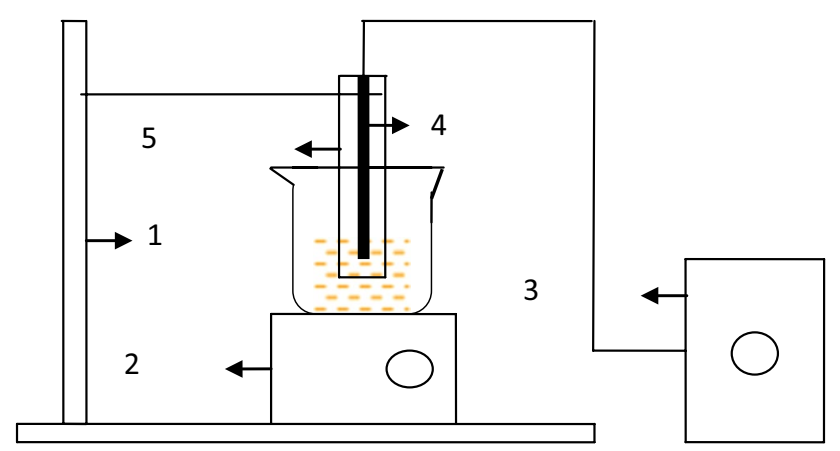

Fig. 2 Photocatalytic reaction device, including iron sets, quartz condensing tube, a xenon lamp, blender, ballast, etc.1. Apparatus stand. 2. Stirrer. 3. Ballast. 4. Xenon. 5. A cooling jacket

was compared with those on both rhodamine talcum and methylene blue (Fig. 2).

\section{Methods}

\section{Preparation of CoMgAI-LDHs}

Sodium hydroxide solution was added into a salt solution prepared by dissolving $\mathrm{Al}\left(\mathrm{NO}_{3}\right)_{3} \cdot 9 \mathrm{H}_{2} \mathrm{O}, 6 \mathrm{H}_{2} \mathrm{O}, \mathrm{Mg}$ $\left(\mathrm{NO}_{3}\right)_{2} \cdot 6 \mathrm{H}_{2}$ and $\mathrm{Co}\left(\mathrm{NO}_{3}\right)_{2}$ in water at $\mathrm{Co} / \mathrm{Mg} / \mathrm{Al}$ molar ratio of $4: 2: 1.2: 2: 1,1: 2: 1,0.5: 2: 1$. The change in the $\mathrm{pH}$ value versus $\mathrm{NaOH}$ was obtained by adding a known volume of $\mathrm{NaOH}$ and the resulting curve (Fig. 3) displayed an optimum $\mathrm{pH}$ value of 9-10. CoMgAl-LDHs were then prepared by co-precipitation method at constant $\mathrm{pH}$ of 9-10.

The $\mathrm{Co} / \mathrm{Mg} / \mathrm{Al}$ salt solutions with molar ratios of 4:2:1, 2:2:1,1:2:1, and 0.5:2:1 were prepared from $\mathrm{Al}\left(\mathrm{NO}_{3}\right)_{3} \cdot 9 \mathrm{H}_{2} \mathrm{O}, \mathrm{Mg}\left(\mathrm{NO}_{3}\right)_{2} \cdot 6 \mathrm{H}_{2} \mathrm{O}$, and $\mathrm{Co}\left(\mathrm{NO}_{3}\right)_{2} \cdot 6 \mathrm{H}_{2} \mathrm{O}$. The prepared $\mathrm{Co} / \mathrm{Mg} / \mathrm{Al}-\mathrm{LDHs}$ salt solutions and the prepared basic solution containing $\mathrm{NaOH}$ and $\mathrm{Na}_{2} \mathrm{CO}$ whose molar ratio was 1:0.5 were added slowly into $100 \mathrm{~mL}$ deionized water. The mixture was continuously stirred and the $\mathrm{pH}$ was kept at 9.3. A gel-like precipitate was obtained. The gel was then placed in a water bath at $60{ }^{\circ} \mathrm{C}$ and the mixture was vigorously stirred. The slurry obtained was then repeatedly washed with deionized water until the $\mathrm{pH}$ reached 7 . The precipitate was then filtered and dried at $80{ }^{\circ} \mathrm{C}$ for $24 \mathrm{~h}$. The solid obtained was ground to about 60-80 mesh. The resulting samples were labeled as CoMgAl-LDHs. These samples were calcined in the furnace to about $400{ }^{\circ} \mathrm{C}$ for $8 \mathrm{~h}$, resulting into composite oxides. All the reagents used are of analytical standard.

\section{Characterization of the sample}

\section{X-ray diffraction (XRD)}

X-ray powder diffraction patterns were recorded using Bruker D8 Advance Type diffractometer to characterize the crystal structure of the prepared samples under the following conditions: electric current $=30 \mathrm{~mA}$, acceleration voltage $=40 \mathrm{kV}$, radiation light source, $\mathrm{CuK} \alpha$ $\lambda=0.15406 \mathrm{~nm}$ rays, scan range $=2-70^{\circ}$, and scanning rate $=0.02 \%$ s.)

\section{UV-visible spectrometry (UV-vis)}

Shimadzu UV-2550 (UV-visible spectrometer) equipped with small sphere diffuse reflectance accessory and $\mathrm{BaSO}_{4}$ reference standard scan of range $200-800 \mathrm{~nm}$ was used.

\section{Adsorption-desorption of nitrogen}

Adsorption-desorption analysis of pore size distribution was conducted using Gold Egyptian Spectrum Technology V-sorb 2800p. BJH method was used and BET equation obtained before the adsorption of the isotherm was calculated.

\section{TG-DTA (DTA-TG) analysis}

This was conducted using the HCT-I analyzer to qualitatively analyze the decomposition process of water. And then hydrotalcite structure was analyzed at a temperature range of about $10-800{ }^{\circ} \mathrm{C}$. 
Fig. 3 CoMgAl-LDHs titration curves of different $\mathrm{Co} / \mathrm{Mg}$ molar ratios $(0.5: 2: 1,1: 2: 1,2: 2: 1$ and $4: 2: 1)$
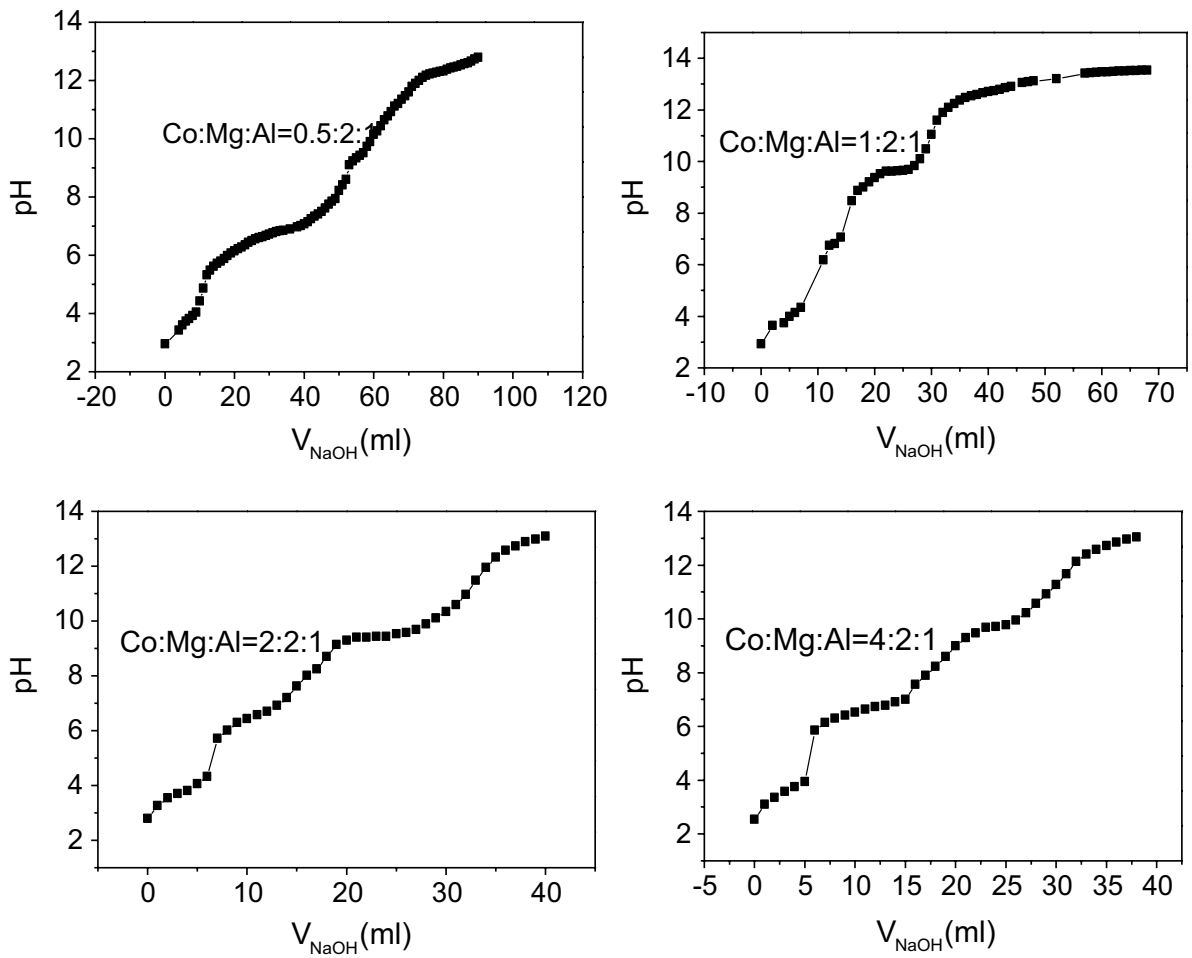

\section{Using SEM (scanning electron microscopy)}

This is one of the most widely used electron microscopes to observe surface morphology such as, the particle dispersion, the grain size, and shape of catalysts. JSM-6360LV model microscope was used.

\section{Photocatalytic activity degradation}

The experiment was carried out in a photocatalytic reactor. A $500 \mathrm{w}$ xenon lamp of wavelength $\lambda>400 \mathrm{~nm}$ was used as a source of light to simulate the visible light. The length of the lamp used was $6 \mathrm{~cm}$ and a light intensity of $1.5 \mathrm{KW} / \mathrm{m}^{2}$.

The xenon was placed in the quartz tube sleeved through a layer of cooling water. The azo dye and catalyst were added into the xenon light through the quarts sleeve and then placed in a dark place for about $2 \mathrm{~h}$ to allow for adsorption dissociation equilibrium. $5 \mathrm{ml}$ of the solution was sampled at an interval of $30 \mathrm{~min}$, centrifuged and the clear solution was added into $4 \mathrm{ml}$ quartz cuvette. The UV-visible spectrophotometer was then used to measure the wavelength of the dyes and the degradation was calculated using the formula presented as Eq. 5:

$D \%=\left(A_{0}-A_{t}\right) / A_{0} \times 100 \%$

where $D$ refers to the degradation of the dye. $A_{0}$ and $A_{t}$ are the absorption at the initial and time $t$, respectively.

\section{Results and discussion}

\section{The optimum pH required to prepare CoMgAI-LDHs}

From Fig. 3, it can be seen that there are 3 distinct peaks: $\mathrm{pH}=12-13, \mathrm{pH}=6-8$ and $\mathrm{pH}=3-5$. Comparing the 4 images, it was found that with different $\mathrm{Co} /$ $\mathrm{Mg}$ molar ratio, the peak range was slightly different. It is clear that the choice of synthesis optimal $\mathrm{pH}$ ranges from $9-10$. The figures show $\mathrm{pH}$ value change curves of

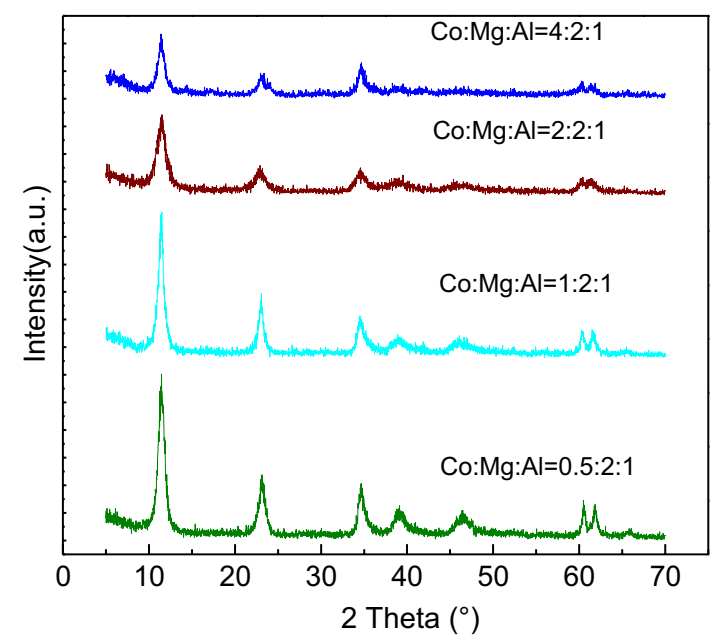

Fig. 4 XRD patterns for CoMgAl-LDHs with different $\mathrm{Co} / \mathrm{Mg} / \mathrm{Al}$ ratios 
CoMgAl-LDHs $=4: 2: 1,2: 2: 1,1: 2: 1$ and 0.5:2:1 against sodium hydroxide solution.

\section{Characterization of samples}

\section{XRD analysis}

XRD patterns of CoMgAl-LDHs Figure 4 shows diffraction pattern of CoMgAl-LDHs. The difference in the intensities of the reflections indicates different degrees of crystallinity [33]. With increase of the second divalent cation $\left(\mathrm{Co}^{2+}\right)$ in hydrotalcite, the XRD peak at $11^{\circ}(\mathrm{d}(003))$ becomes broader with increasing moles of $\mathrm{Co}$, indicating a more disordered structure or a decrease in crystallinity [33]. The peak at about $11^{\circ} 2$-teta for all sample of hydrotalcite are attributed to the reflections from (003) of crystallographic planes. The $a$ and $c$ values of each sample cell can be calculated based on the numerical value of the diffraction and the $d$ value [37]. The parameter $a$ of hydrotalcite be calculated by $a=$ $2 \times \mathrm{d} 110$. On the other hand, the $\mathrm{c}$ parameter can be obtained from $c=3 \times \mathrm{d} 003$.

XRD patterns of CoMgAI-LDO The Fig. 5 shows the XRD pattern of CoMgAl-LDO after calcination at $400{ }^{\circ} \mathrm{C}$ for $8 \mathrm{~h}$. From the XRD pattern, the peaks at $37^{\circ}, 44^{\circ}$, and $64^{\circ}$ are the characteristics diffraction peaks of hydrotalcite structure, the samples prepared by baking at $400{ }^{\circ} \mathrm{C}$ generated composite oxides.

XRD of CoMgAl-LDHs after adsorption of methyl orange to saturation The Fig. 6 shows the XRD pattern of calcined CoMgAl-LDHs after methyl orange adsorption. The patterns at $11^{\circ}, 23^{\circ}, 34^{\circ}, 39^{\circ}, 46^{\circ}, 60^{\circ}$, and $62^{\circ}$ are the char-

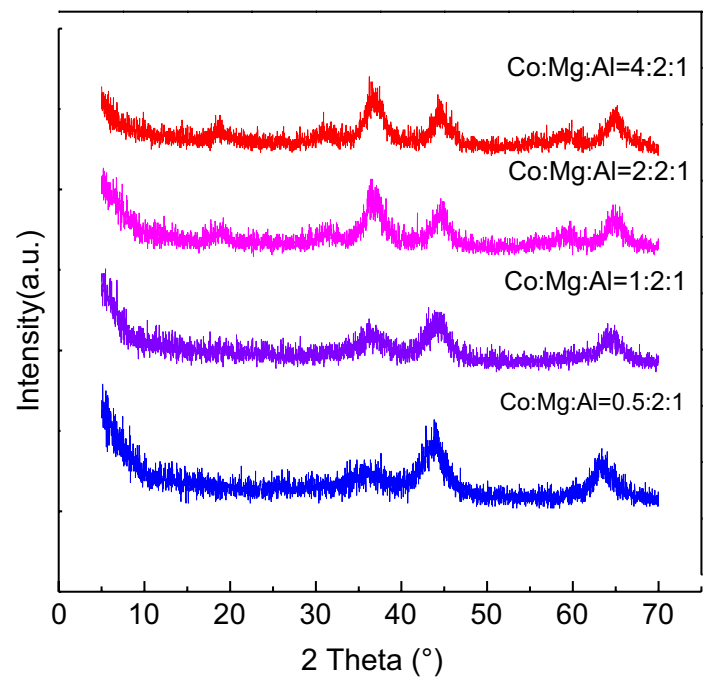

Fig. 5 XRD spectra of CoMgAl-LDHs derived oxides with different $\mathrm{Co} / \mathrm{Mg}$ molar ratios

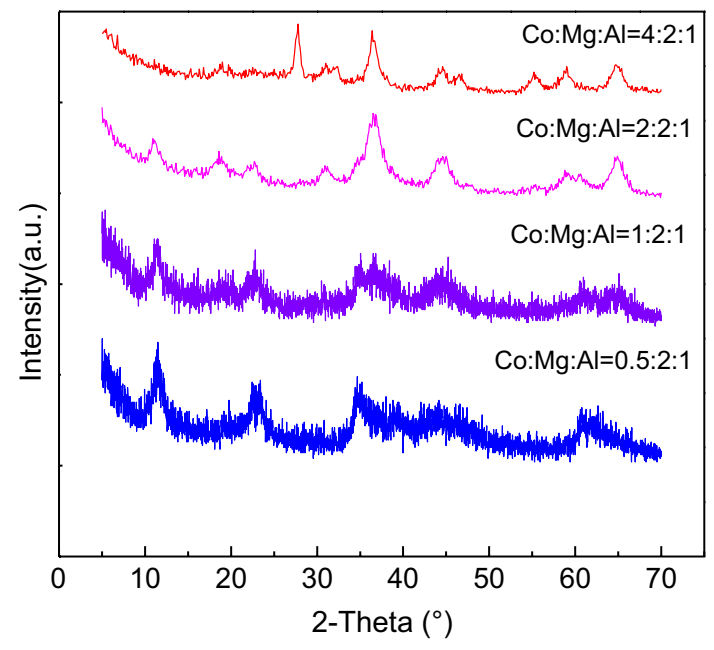

Fig. 6 XRD spectra of CoMgAl-LDHs after methyl orange adsorption

acteristics diffraction peaks of hydrotalcite structure. This indicates that the calcined samples have absorbed methyl orange to saturation. Thus, the hydrotalcite structure has been restored, an evidence of "memory effect" [31].

\section{Differential thermal gravimetric analysis (TG-DTA)}

The Fig. 7 represents CoMgAl-LDHs $(\mathrm{Co} / \mathrm{Mg} / \mathrm{Al}=1: 2: 1)$ differential thermal gravimetric analysis. The downward peak is an endothermic corresponds to the physical removal of adsorbed water below $100{ }^{\circ} \mathrm{C}$. Above $100{ }^{\circ} \mathrm{C}$, there are two distinct weight losses. The first phase exhibits endothermic peak corresponds to the interlayer water molecule removal. The second phase exhibits an endothermic peak corresponds to dehydroxylation and decarbonation of the layer [36].With the addition of the second divalent cation (Co) in the brucite-like structure, $\mathrm{Co}-\mathrm{Mg}-\mathrm{Al}$-hydrotalcite

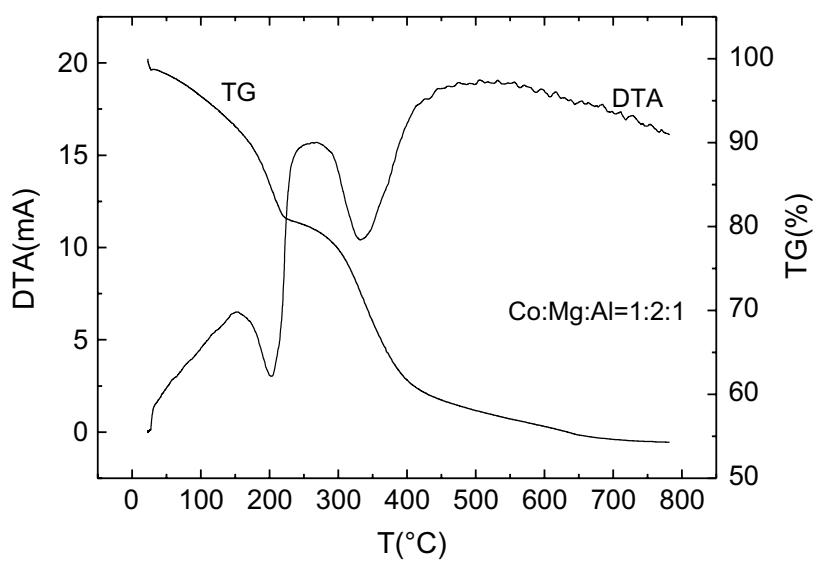

Fig. 7 TG-DTA of CoMgAl-LDH= 1:2:1 ratio 
Table 1 The thermal decomposition data of CoMgAl-LDHs 1:2:1 ratio

\begin{tabular}{lllll}
\hline $\begin{array}{l}\text { CoMgAl } \\
\text { molar ratio }\end{array}$ & $\begin{array}{l}\text { Water layer } \\
\text { dehydration } \\
\text { peak tem- } \\
\text { perature }\end{array}$ & $\begin{array}{l}\text { First stage } \\
\left({ }^{\circ} \mathrm{C}\right) \text { weight } \\
\text { loss rate } \\
(\%)\end{array}$ & $\begin{array}{l}\mathrm{OH}^{-} \text {and } \\
\mathrm{CO}_{3}^{2-} \\
\text { decomposi- } \\
\text { tion peak } \\
\text { temperature } \\
\left({ }^{\circ} \mathrm{C}\right)\end{array}$ & $\begin{array}{l}\text { Second stage } \\
\text { weight loss } \\
\text { rate }(\%)\end{array}$ \\
\hline $1: 2: 1$ & 203 & 15.4 & 332 & 27.1 \\
\hline
\end{tabular}

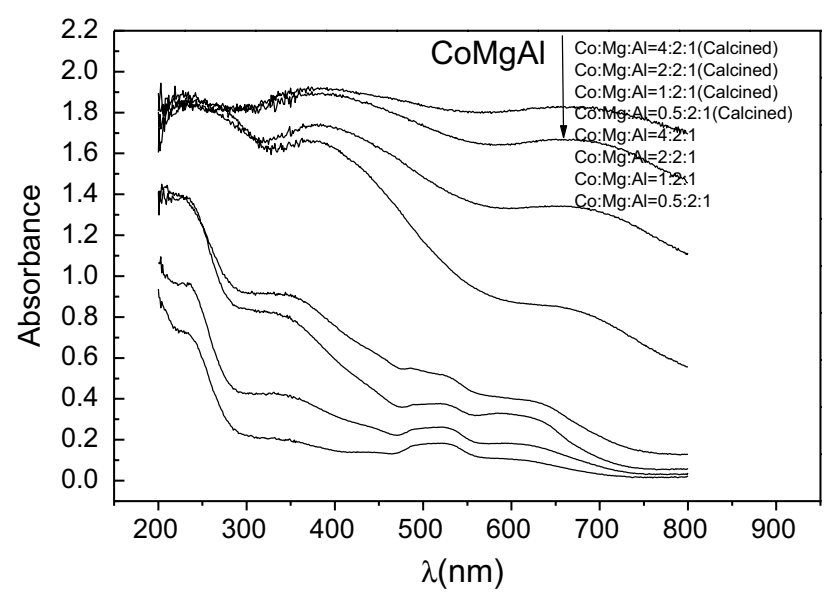

Fig. $8 \mathrm{UV}-\mathrm{Vis}$ spectra of CoMgAl-LDHs with different $\mathrm{Co} / \mathrm{Mg}$ molar ratios

exhibits lower thermal stability. Table 1 below shows the data for the corresponding thermal decomposition data.

\section{UV-vis diffuse reflectance spectroscopy analysis}

UV-vis diffuse reflectance absorption spectra Figure 8 shows the UV-visible diffuse reflectance spectra of Co:Mg:Al (= 4:2:1, 2:2:1, 1:2:1 and 0.5:2:1). The results from the spectrum show that, except at 400 or less, CoMgAl-LDHs show a stronger absorption of ultraviolet light. There is also obvious absorption peak at a wavelength of $520 \mathrm{~nm}$ in the visible region. $\mathrm{Co}: \mathrm{Mg}: \mathrm{Al}=4: 2: 1$ and $\mathrm{Co}: \mathrm{Mg}: \mathrm{Al}=2: 2: 1$ samples showed a tiny absorption peak at a wavelength of $640 \mathrm{~nm}$ (Table 2). It is clear that CoMgAl-

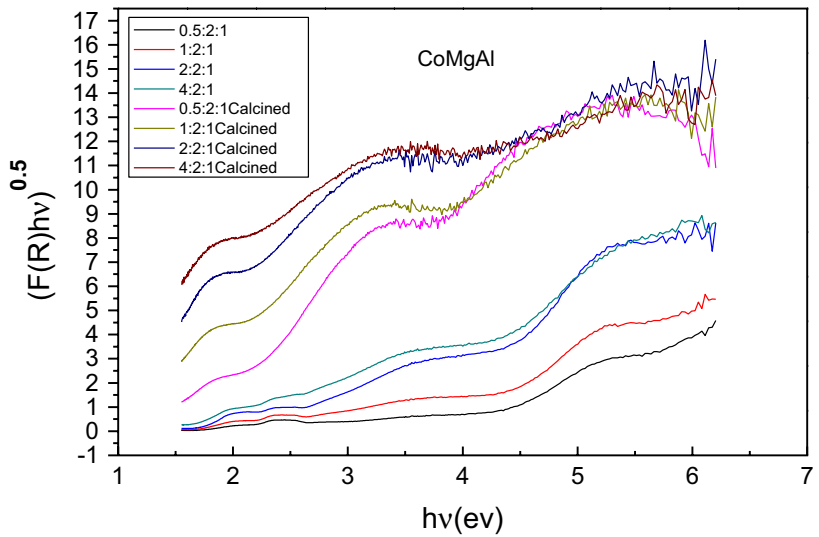

Fig. 9 UV-Vis spectra of CoMgAl-LDHs with different $\mathrm{Co} / \mathrm{Mg}$ molar ratio

LDHs showed visible light absorption features. It can be seen that an increase in Co content in the samples causes an increase in light absorption ability both in the visible and ultraviolet region along with obvious red shift [3].

UV-vis diffuse reflectance absorption spectra of Co:Mg:Al=0.5:2:1, 1:2:1, 2:2:1, and 4:2:1 Figure 9 shows the UV-visible diffuse reflectance absorption spectra, $\mathrm{h} \nu$ on the horizontal axis while $\mathrm{Co}: \mathrm{Mg}: \mathrm{Al}(=0.5: 2: 1,1: 2: 1,2: 2: 1$, and 4:2:1) on the vertical axis.

$F(R)=\frac{(1-R)^{2}}{2 R}$

$h c / \lambda_{0}=1240 / \lambda_{0}=h v$

Equation 6 is for $\mathrm{K}-\mathrm{M}$ function,

where $R=$ relatively diffuse reflectance, $h$, the Planck's constant $=6.62176 \times 10^{-34} \mathrm{~J} \mathrm{~s}, c$, speed of light $=3 \times 108 \mathrm{~m} / \mathrm{s}$. Absorption limit $\lambda_{0}$ made by the absorption edge tangent to determine the intersection of the horizontal axis. They were done in tangent of $\mathrm{Co}: \mathrm{Mg}: \mathrm{Al}=0.5: 2: 1, \mathrm{Co}: \mathrm{Mg}: \mathrm{Al}=1: 2: 1, \mathrm{Co}: \mathrm{Mg}: \mathrm{Al}=2: 2: 1$ and $\mathrm{Co}: \mathrm{Mg}: \mathrm{Al}=4: 2: 1, \lambda_{0}$ was calculated according to the band gap formula corresponding to listed in Table 3 . The narrow the band gap the higher the utilization rate of visible light by the sample.
Table 2 Band gap and CoMgAl-LDHs precursors after calcination

\begin{tabular}{lllll}
\hline Precursor & & & After calcination \\
\cline { 5 - 6 } Sample & Band gap $(\mathrm{eV})$ & & Sample & Band gap (eV) \\
\hline Co:Mg:Al=4:2:1 & 2.12 & & Co:Mg:Al=4:2:1 & 0.25 \\
Co: $\mathrm{Mg}: \mathrm{Al}=2: 2: 1$ & 2.67 & & Co:Mg:Al=2:2:1 & 0.89 \\
Co: $\mathrm{Mg}: \mathrm{Al}=1: 2: 1$ & 3.45 & & Co:Mg:Al=1:2:1 & 1.48 \\
Co:Mg:Al=0.5:2:1 & 3.96 & & Co:Mg:Al $=0.5: 2: 1$ & 1.88 \\
\hline
\end{tabular}


Table 3 CoMgAl-LDHs 3 precursor adsorption data of nitrogen

\begin{tabular}{lc}
\hline Sample & $\begin{array}{l}\text { Specific } \\
\text { surface area/ } \\
\left(\mathrm{m}^{2} / \mathrm{g}\right)\end{array}$ \\
\hline $\mathrm{Co}: \mathrm{Mg}: \mathrm{Al}=0.5: 2: 1$ & 66.23 \\
$\mathrm{Co}: \mathrm{Mg}: \mathrm{Al}=1: 2: 1$ & 112.85 \\
$\mathrm{Co}: \mathrm{Mg}: \mathrm{Al}=2: 2: 1$ & 40.13 \\
$\mathrm{Co}: \mathrm{Mg}: \mathrm{Al}=4: 2: 1$ & 48.13 \\
\hline
\end{tabular}

\section{SEM-scanning electron microscope analysis}

The morphologies of these samples are shown in Fig. 10. As seen in the images after adsorption treatment, the CoMgAl-LDHs formed lamellar structure, the sheet of layers stacked to one another but evenly distributed. However, $\mathrm{Co}: \mathrm{Mg}: \mathrm{Al}=2: 2: 1$ exhibited low accumulation level. Furthermore, it can be seen that there was an increase in the aggregation degree in $\mathrm{Co}: \mathrm{Mg}: \mathrm{Al}=4: 2: 1$ but there wasn't obvious lamellar structure. When the Co content was increased, the sheets became irregular; it was difficult to observe the lamellar morphology [33]. From the images after they had been calcined at $400{ }^{\circ} \mathrm{C}$, the LDHs layer could not be observed. The hydrotalcites' layered structure in LDHs was restored after being treated and roasted. This clearly indicates "memory effect" existence $[5,10,24]$.

\section{Nitrogen adsorption desorption analysis}

Figure 11 shows $\mathrm{N}_{2}$ adsorption-desorption isotherm of CoMgAl-LDHs.

The Table 3 shows $\mathrm{N}_{2}$ physical adsorption data of Co:Mg:Al = 0.5:2:1, Co:Mg:Al = 1:2:1, Co:Mg: $\mathrm{Al}=2: 2: 1$ and $\mathrm{Co}: \mathrm{Mg}: \mathrm{Al}=4: 2: 1$. It can be seen from the Table 3 that, $\mathrm{Co}: \mathrm{Mg}: \mathrm{Al}=1: 2: 1$ possessed larger specific surface area.

\section{Degradation activity of photocatalytic}

\section{Degradation rate and the effect of varying $\mathrm{Co} / \mathrm{Mg} / \mathrm{Al}$ molar ratio}

In the experimental process, aqueous solution of methyl orange (azo dye) was used as the processing object on the photocatalytic degradation study. The methyl orange azo structure is shown in the Fig. 12.

Hydrotalcite has unique layered structure and strong adsorption. Before carrying out the photocatalytic degradation process, adsorption to saturation after the calcination of the CoMgAl-LDHs was conducted. $1 \mathrm{~g} / \mathrm{L}$ catalyst and $40 \mathrm{mg} / \mathrm{L}$ of methyl orange solution were used. The result of methyl orange visible light photocatalytic degradation with different molar ratio of $\mathrm{Co} / \mathrm{Mg} / \mathrm{Al}$ in $\mathrm{CoMgAl}-\mathrm{LDHs}$ is shown in Fig. 11.

From Fig. 13, CoMgAl-LDHs with different CoMgAl molar ratios were used in photocatalytic degradation of methyl orange. When $\mathrm{Co} / \mathrm{Mg}=1: 2$ was used, the photocatalytic degradation rate is higher and the basic balance could be achieved within $1 \mathrm{~h}$. This is due to its larger surface area as seen in nitrogen adsorption-desorption analysis (Table 3), the synthesized CoMgAl-LDH(Co/Mg=1:2) was found to have high surface area and good sorption abilities, thus providing more MO dye molecules with access to external surface. The methyl orange degradation over CoMgAlLDHs is proposed to be due to the formation of intermediate oxidative species such as hydroxyl radicals and superoxide radicals during the reactions [38]. The overall degradation reaction mechanism of methyl orange in aqueous solution can be represented as:

$\mathrm{Co} / \mathrm{Mg}-\mathrm{Al}-\mathrm{LDHs}\left(\mathrm{MO}_{6}\right)+h \gamma \rightarrow h v_{\mathrm{VB}}^{+}+\mathrm{e}_{\mathrm{CB}}^{-}$

$h v_{\mathrm{VB}}+\mathrm{H}_{2} \mathrm{O} \rightarrow 2 \mathrm{H}^{+}+2 \mathrm{OH}^{\circ}$

$\mathrm{e}_{\mathrm{CB}}^{-}+\mathrm{O}_{2} \rightarrow \mathrm{O}_{2}^{-}$

$\mathrm{O}_{2}^{--}+\mathrm{H}^{+} \rightarrow \mathrm{HO}_{2}^{-}$

$\mathrm{HO}_{2}^{\circ}+\mathrm{HO}_{2}^{-} \rightarrow \mathrm{H}_{2} \mathrm{O}_{2}$

$\mathrm{H}_{2} \mathrm{O}_{2} \rightarrow 2 \mathrm{OH}$

$\mathrm{MO}$ dye $+\mathrm{OH}^{-}$or $\mathrm{O}_{2}^{--} \rightarrow$ degradation products

Furthermore, a comparative photo-degradation of various dyes (rhodamine and methylene blue) in addition to methyl orange over the most active ( $\mathrm{LDH}-\mathrm{Co} / \mathrm{Mg}=1: 2)$ was carried out to access the future photocatalytic application of this catalyst (Fig. 14).

\section{Effect of the catalysts on the degradation rate for various dyes}

Figure 14 below shows degradation rate of rhodamine, methylene blue and methyl orange, respectively. Co: $\mathrm{Mg}: \mathrm{Al}=1: 2: 1$ catalyst ( $1 \mathrm{~g} / \mathrm{L}$ hydrotalcite precursors) was selected. It was observed from the curves that, the photocatalytic effect of the catalyst on the degradation rate for methyl orange was more significant as compared with the effect on rhodamine talcum and methylene blue.

\section{Conclusion}

In this work, CoMgAl-LDHs were successfully prepared by co-precipitation method and various techniques such as UV-vis, BET, TG-DTA, SEM analysis, and XRD were used 
Fig. 10 SEM images of

CoMgAl-LDHs. SEM images

of $\mathrm{Co}: \mathrm{Mg}: \mathrm{Al}=2: 2: 1$ after

calcination. SEM analysis

images of $\mathrm{Co}: \mathrm{Mg}: \mathrm{Al}=4: 2: 1$

after calcination. SEM images

of $\mathrm{Co}: \mathrm{Mg}: \mathrm{Al}=2: 2: 1$ after

adsorption. SEM analysis image

of $\mathrm{Co}: \mathrm{Mg}: \mathrm{Al}=4: 2: 1$ after

adsorption

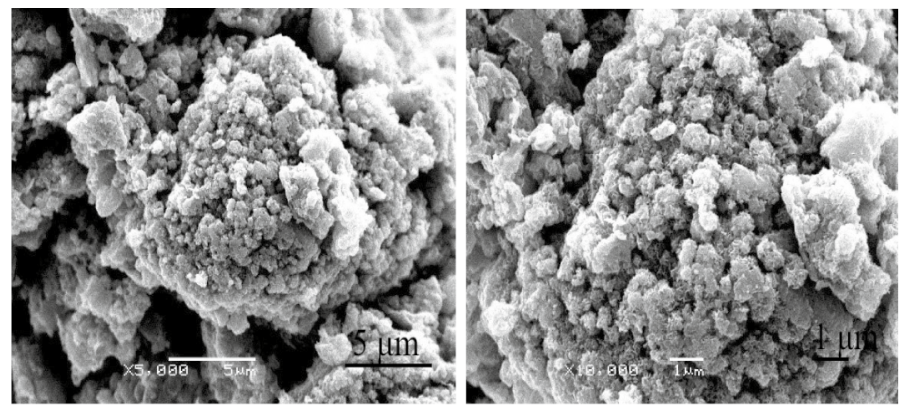

SEM images of Co:Mg:Al=2:2:1 after calcination
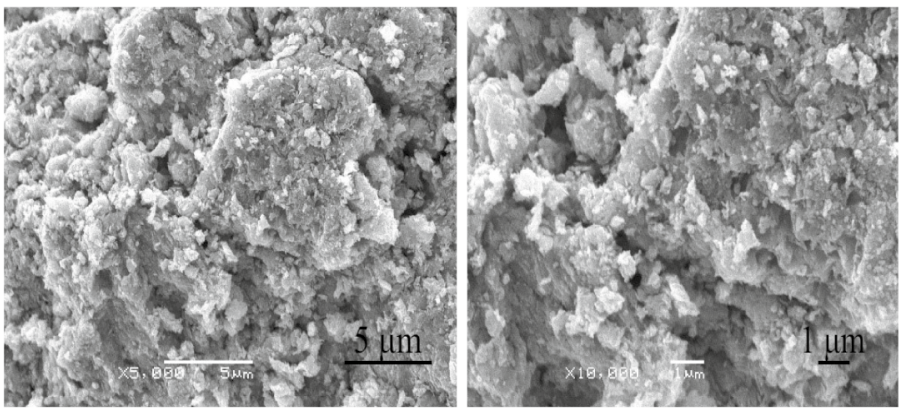

SEM analysis images of $\mathrm{Co}: \mathrm{Mg}: \mathrm{Al}=4: 2: 1$ after calcination.
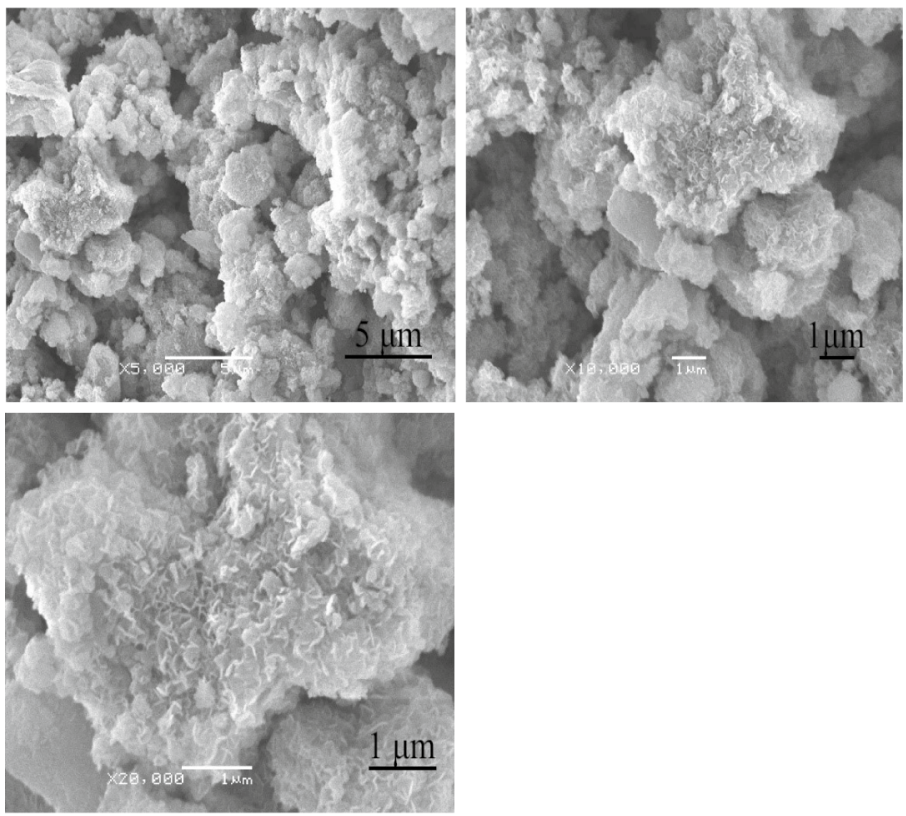

SEM images of $\mathrm{Co}: \mathrm{Mg}: \mathrm{Al}=2: 2: 1$ after adsorption
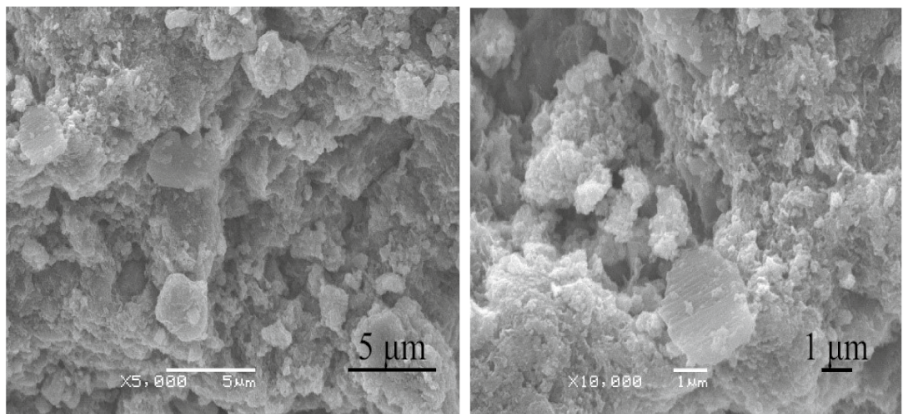

SEM analysis image of Co:Mg:Al=4:2:1 after adsorption. 
Fig. 11 Nitrogen adsorption desorption isotherms of CoMgAl-LDHs

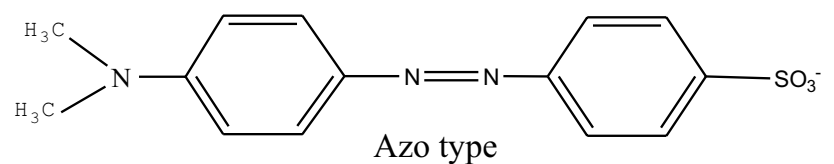

Fig. 12 The molecular structure of methyl orange azo type

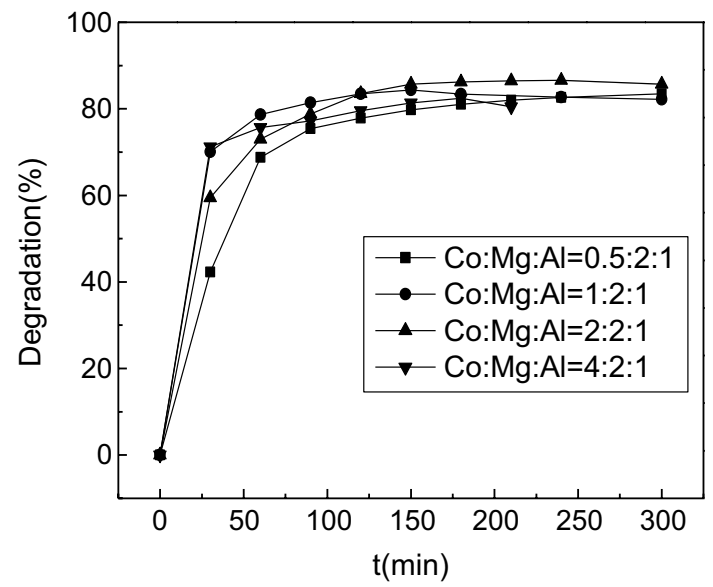

Fig. 13 Methyl orange degradation using different $\mathrm{Co} / \mathrm{Mg} / \mathrm{Al}$ molar ratio in CoMgAl-LDHs

to investigate the catalytic activity, structure and composition of the prepared samples. The crystallinity of the CoMgAl-LDHs was observed to vary with Co molar ratio. Morphological analysis, by SEM method, revealed the formation of layered double hydroxides crystals and their cohesion
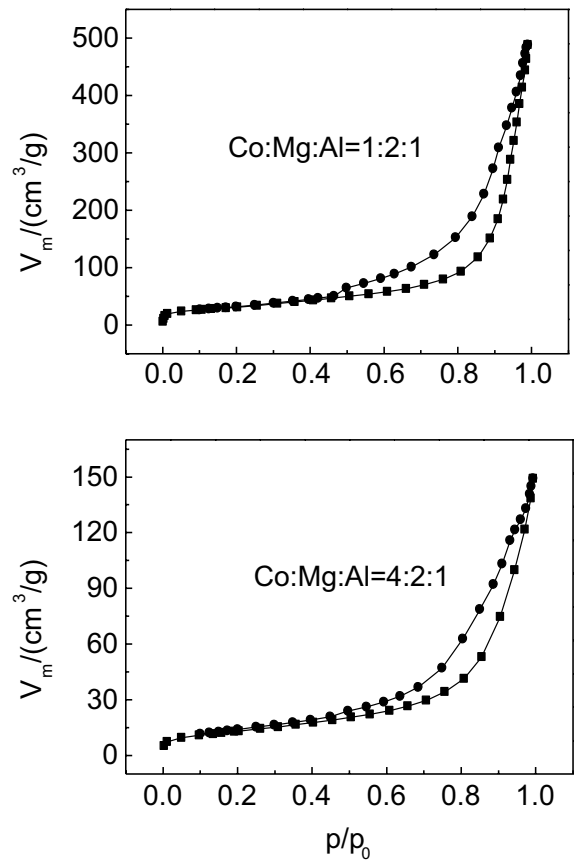
Acknowledgements The authors are grateful to China National Natural Science Foundation (No. 51374066, 51304047), the National Key Technology R\&D Program (No. 2014BAC03B07), and Industrial Research Projects, Liaoning Province (No. 2012223002, 2014020037) for the financial support in ensuring successful completion of this project.

Open Access This article is distributed under the terms of the Creative Commons Attribution 4.0 International License (http://creativeco mmons.org/licenses/by/4.0/), which permits unrestricted use, distribution, and reproduction in any medium, provided you give appropriate credit to the original author(s) and the source, provide a link to the Creative Commons license, and indicate if changes were made.

\section{References}

1. Fujishima A, Honda K (1971) Electrochemical evidence for the mechanism of the primary stage of photosynthesis. Bull Chem Soc Jpn 44:1148-1150

2. Duan X, Wang G, Wang H, Wang Y, Shen C, Cai W (2010) Orientable pore-size-distribution of $\mathrm{ZnO}$ nanostructures and their superior photocatalytic activity. CrystEngComm 12(10):2821-2825

3. Dambar B. Hamal Design and development of a new generation of Uv-Vis-light driven nano sized codoped titanium dioxide photocatalyst and biocides/sporocides, and environmental applications. (2009) p. 8-11

4. Paramasivam I, Jha H, Liu N, Schmuki P (2012) A review of photocatalysis using self-organized $\mathrm{TiO}_{2}$ nanotubes and other ordered oxide nanostructures. Small 8:3013-3073

5. Momeni MM, Hakimian M (2015) A Kazempour In-situ manganese doping of $\mathrm{TiO}_{2}$ nanostructures via single-step electrochemical anodizing of titanium in an electrolyte containing potassium permanganate: a good visible-light photocatalyst. Ceram Int 0272-8842:07.158

6. Momeni MM, Ghayeb Y, Ghonchegi Z (2015) Visible light activity of sulfur-dope $\mathrm{TiO}_{2}$ nanostructure photo-electrodes prepared by single-step electrochemical anodizing process. Solid State Electrochem 19:1359-1366

7. Momeni MM (2015) Fabrication of copper decorated tungsten oxide- $\mathrm{TiO}_{2}$ nanotubes by photochemical deposition technique and their photocatalytic application under visible light. Appl Surf Sci 357:160-166

8. Momeni MM, Ghayeb Y, Ezati F (2018) Fabrication, characterization and photo electrochemical activity of tungsten-copper co-sensitized $\mathrm{TiO}_{2}$ nanotube composite photo anodes. J Colloid Interface Sci 514:70-82

9. Zhou Q, Fang Z, Li J, Wang M (2015) Applications of $\mathrm{TiO}_{2}$ nanotube arrays in environmental and energy fields: a review. Microporous Mesoporous Mater 202:22-35

10. Zhang N, Liu S, Fu X, Xu YJ (2011) Synthesis of M@ $\mathrm{TiO}_{2}$ $(\mathrm{M}=\mathrm{Au}, \mathrm{Pd}, \mathrm{Pt})$ core-shell nanocomposites with tunable photoreactivity. J Phys Chem C 115(18):9136-9145

11. Xu YJ, Zhuang Y, Fu X (2010) New insight for enhanced photocatalytic activity of $\mathrm{TiO}_{2}$ by doping carbon nanotubes: a case study on degradation of benzene and methyl orange. J Phys Chem C 114(6):2669-2676

12. Forano C, Hibino T (2006) Leroux, developments in clay soil, vol 1. Elsevier, Amsterdam, pp 1021-1095

13. Vaccari A (1998) Preparation and catalytic properties of cationic and anionic clays. Catal Today 41:53-71. https://doi. org/10.1016/s0920-5861(98)00038-8
14. G. Defontaine, L.J. Michot, I. Bihannic, J. Ghanbaja, V. Briois, Synthesis of $\mathrm{NiGa}$ layered double hydroxides. A combined EXAFS, SAXS, and TEM study. 3. Synthesis at constant $\mathrm{pH}$, Langmuir 20 (25) (2004) 11213-11222, doi:http://dx.doi. org/10.1021/la048681p

15. Mohapatra L, Parida K (2016) A review on the recent progress, challenges and perspective of layered double hydroxides as promising photocatalysts. J Mater Chem A 4:10744

16. Pathania D, Sharma G, Kumar A, Naushad M, Kalia S, Sharma A, AL Othman ZA (2015) Combined sorptional-photocatalytic remediation ofdyes by polyaniline $\mathrm{Zr}(\mathrm{IV})$ selenotungstophosphate nanocomposite. Toxicol Environ Chem 97(5):526-537. https://doi.org/10.1080/02772248.2015.1050024

17. Baliarsingh N, Mohapatra L, Parida K (2013) Design and development of a visible light harvesting $\mathrm{Ni}-\mathrm{Zn} / \mathrm{Cr}-\mathrm{CO}_{3}{ }^{2-} \mathrm{LDH}$ system for hydrogen evolution. J Mater Chem A 1:4236

18. Mohapatraab L, Parida KM (2014) Dramatic activities of vanadate intercalated bismuth doped LDH for solar light photocatalysis. Phys Chem Chem Phys 16:16985

19. Parida K, Mohapatra L, Baliarsingh N (2012) Effect of $\mathrm{Co}^{2+}$ substitution in the framework of carbonate intercalated $\mathrm{Cu} / \mathrm{Cr} \mathrm{LDH}$ on structural, electronic, optical, and photocatalytic properties. J Phys Chem C 116:22417-22424

20. Sharma G, Kumar A, Sharma S, Al-Saeedi SI, Al-Senani GM, Nafady A, Ahamad T, Naushad M, Stadler FJ (2019) Fabrication of oxidized graphite supported $\mathrm{La}_{2} \mathrm{O}_{3} / \mathrm{ZrO}_{2}$ nanocomposite for the photoremediation of toxic fast green dye. J Mol Liq 277:738-748

21. Pathania D, Gupta D, Al-Muhtaseb AH, Sharma G, Kumar A, Naushad M, Ahamad T, Alshehri SM (2016) Photocatalytic, degradation of highly toxic dyes using chitosan-g-poly (acrylamide)/ $\mathrm{ZnS}$ in presence of solar irradiation. J Photochem Photobiol A Chem 329:61-68

22. Kumar A, Sharma G, Naushad M, Singh P, Kalia S (2014) Polyacrylamide/Ni $0.02 \mathrm{Zn} 0.98 \mathrm{O}$ nanocomposite with high solar light photocatalytic activity and efficient adsorption capacity for toxic dye removal. Ind Eng Chem Res 53:15549-15560

23. Sirajuddin, V. Gupta, G. Sharma, A. Kumar, F. J. Stadler, Inamuddin (2019) Preparation and characterization of Gum Acacia/

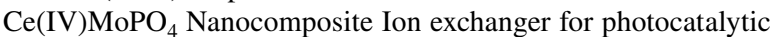
degradation of methyl violet dye, J Inorganic Organomet Polym Mater https://doi.org/10.1007/s10904-019-01080-9

24. Sahoo DP, Nayak S (2018) Fabrication of a $\mathrm{Co}(\mathrm{OH}) \mathrm{LDH}$ "p-n" heterojunction photocatalyst with enhanced separation of charge carriers for efficient visible-light $\mathrm{H}_{2}$ and $\mathrm{O}_{2}$ evolution. Inorg Chem 57(7):3840-3854

25. Nayak S, Mohapatra L, Parida K (2015) Visible-light driven novel g- $\mathrm{C}_{3} \mathrm{~N}_{4} / \mathrm{NiFe}-\mathrm{LDH}$ composite photocatalyst with enhanced photocatalytic activity towards water oxidation and reduction reaction. Mater Chem A 3:18622-18635

26. Gardner E, Huntoon KM, Pinnavaia TJ (2001) Direct synthesis of alkoxide-intercalated derivatives of hydrocalcite-like layered double hydroxides: precursors for the formation of colloidal layered double hydroxide suspensions and transparent thin films. Adv Mater 13(16):1263-1266. https://doi.org/10.1002/15214095(200108)

27. Cai H, Hillier AC, Franklin KR, Nunn CC, Ward MD (1994) Nanoscale imaging of molecular adsorption. Science 266(5190):1551-1555. https://doi.org/10.1126/scien ce.266.5190.1551

28. Nayak S, Parida KM (2018) Dynamics of charge-transfer behavior in a plasmon-induced quasi-type-II $\mathrm{p}-\mathrm{n} / \mathrm{n}-\mathrm{n}$ dual heterojunction in $\mathrm{Ag} @ \mathrm{Ag}_{3} \mathrm{PO}_{4} / \mathrm{g}-\mathrm{C} 3 \mathrm{~N} 4 / \mathrm{NiFeLDH}$ nanocomposites for photocatalytic $\mathrm{Cr}(\mathrm{VI})$ reduction and phenol oxidation. ACS Omega 3:7324-7343

29. Costantino U, Marmottini F, Nochetti M, Vivani R (1998) The synthesis of $\mathrm{Mg}-\mathrm{Zn}-\mathrm{Al} \mathrm{LDH}$ and the sustained-release properties 
of theophylline intercalated LDH. Eur J Inorg Chem 10:14391446. https://doi.org/10.4028/www.scientific.net/AMR.18919 3.2448

30. Lopez T, Bosch P, Ramos E, Gomez R, Novaro O, Acosta D, Figueras F (1996) Synthesis and characterization of sol-gel hydrotalcites. Structure and texture, Langmuir 12 (1):189-192, doi:http://dx.doi.org/10.1021/la940703s. K. Shekoohi et al./MethodsX 4 (2017) 86-94 93

31. Prinetto F, Ghiotti G, Graffin P, Tichit D (2000) Synthesis and characterization of sol-gel $\mathrm{Mg} / \mathrm{Al}$ and $\mathrm{Ni} / \mathrm{Al}$ layered double hydroxides and comparison with co-precipitated samples. Microporous Mesoporous Mater 39:229-247. https://doi. org/10.1016/s1387-1811(00)00197-9

32. Hou MF, Li FB, Li RF, Wan HF, Zhou GY, Xie KC (2004) Enhancement of photo-catalytic properties and activity of $\mathrm{Nd}^{3}$ p-doped $\mathrm{TiO}_{2}$ powders. J Chin Rare Earth Soc 22:75-80

33. Aramendia MA, Borau V, Jimenez C, Marinas JM, Romero FJ, Urbano FJ (1999) Synthesis and characterization of a novel Mg/ In layered double hydroxide. J Mater Chem 9(2016):2291-2292. https://doi.org/10.1039/A906148G

34. Behrens M, Kasatkin I, Kuhl S, Weinberg G (2016) Phase-pure $\mathrm{Cu}, \mathrm{Zn} \mathrm{Al} \mathrm{hydrotalcite-like} \mathrm{materials} \mathrm{as} \mathrm{precursors} \mathrm{for} \mathrm{copper} \mathrm{rich}$ $\mathrm{Cu} / \mathrm{ZnO} / \mathrm{Al}_{2} \mathrm{O}_{3}$ catalysts. Chem Mater 22(2):386-397. https://doi. org/10.1021/cm9029165
35. Perez-Lopez OW, Senger A, Marcilio N, Lansarin MA (2006) Effect of composition and thermal pretreatment on properties of $\mathrm{Ni}-\mathrm{Mg}-\mathrm{Al}$ catalysts for $\mathrm{CO}_{2}$ reforming of methane. Appl Catal A 303(2):234-244. https://doi.org/10.1016/j.apcata.2006.02.024

36. Shekoohi K, Hosseini FS, Haghighi AH, Sahrayian A (2017) Synthesis of some $\mathrm{Mg} / \mathrm{Co}-\mathrm{Al}$ type nano hydrotalcites and characterization. MethodsX 4:86-94

37. Motokura K, Fujita N, Mori K, Mizugaki T, Ebitani K, Kaneda $\mathrm{K}$ (2005) An acidic layered clay is combined with a basic layered clay for one-pot sequential reactions. J Am Chem Soc 127(27):9674-9675. https://doi.org/10.1021/ja052386p

38. Baliarsingh L, Parida KM, Pradhan GC (2014) Effects of Co, Ni, and $\mathrm{Zn}$ on photophysical and photocatalytic properties of carbonated intercalated $\mathrm{M}^{2+} / \mathrm{Cr} \mathrm{LDH}$ for enhanced photo-degradation of methyl orange. Ind Eng Chem Res 53(10):3834-3841

Publisher's Note Springer Nature remains neutral with regard to jurisdictional claims in published maps and institutional affiliations. 